\title{
WASTE GLASS POWDER-BASED ALKALI-ACTIVATED MORTAR
}

\author{
Ana Balaguer Pascual ${ }^{1}$, Monique Tohoue Tognonvi ${ }^{2}$, Arezki Tagnit-Hamou ${ }^{3}$ \\ ${ }^{I}$ Department of Civil Engineering, University of Sherbrooke, Quebec, Canada \\ ${ }^{2}$ Department of Civil Engineering, University of Sherbrooke, Quebec, Canada \\ ${ }^{3}$ Department of Civil Engineering, University of Sherbrooke, Quebec, Canada
}

\begin{abstract}
The global warming ensues from the emission of large amount of greenhouse gases in the atmosphere. The part of the carbon footprint attributed to the concrete becomes more and more important due to the cement content and the increase of the worldwide demand for concrete. Although much is done to reduce the environmental impact of concrete with the use of supplementary cementitious materials, the best alternative can be the development of new Portland cement-free binder through alkali-activation of waste products. This paper deals with the development of waste glass powder (GP) based alkali-activated mortar. Metakaolin (MK) is used to replace a part of glass powder in order to introduce Al and also to stabilize alkali ions in the system. The effect of $\mathrm{NaOH}$ concentration and $\mathrm{MK}$ content on the mechanical and microstructural properties of mortars are studied. Results show a gradual increase in the mechanical properties of the mortar with more cohesion between the paste and sand aggregates when $M K$ is added up to 8\%. In contrast, without MK or with less than $3 \%$ of MK content, the compressive strength decreases with the time with a poor cohesion between the paste and aggregates. Moreover, the NaOH concentration of $5 M$ is enough to activate the studied system as a high level of concentration induces a delay in the geopolymer gel formation. According to the first results, this glass powder based geopolymer seems promising and further studies need to be carried out.
\end{abstract}

Keywords: carbon footprint, glass powder, geopolymer concrete, cementitious material, alkali-activation $* * *$

\section{INTRODUCTION}

Concrete is one of the most widely used building materials in the world. The cement constitutes the main element that provides the binding and the good mechanical properties of concrete. The demand in cement keeps on increasing due to the global population growth particularly in the emerging and developing countries [1]. The demand of cement for 2010 was estimated at 3310 million metrics [2]. However, the cement industry produces 5 to $8 \%$ of the atmospheric $\mathrm{CO}_{2}$ in the world [3]. The production of one tonne of clinker, which accounts for $95 \%$ of the Portland cement composition, generates about one tonne of $\mathrm{CO}_{2}$. The carbon dioxide $\left(\mathrm{CO}_{2}\right)$, largely responsible for the increase in greenhouse gas effect, contributes significantly to climate change [4] resulting in the rise of the global average surface and sub-surface ocean temperatures [5]. Although much is done to reduce the environmental impact of concrete with the use of supplementary cementitious materials in replacement of part of the cement, the carbon footprint of concrete remains high. One of the best alternative can be the development of new Portland cement-free binder through alkali-activation of waste products. These binders known as alkali-activated materials have been studied for the first time and patented in 1908 by Kühl [6] who, by combining a vitreous slag and an alkali sulfate or carbonate with or without added alkali earth oxides or hydroxides obtained a good performance materials comparable to Portland cement. Purdon [7,8] is the first one who developed in more detail the scientific basis for these binders in 1940 by testing several different blast furnace slags activating by sodium hydroxide or by the combination of $\mathrm{Ca}(\mathrm{OH})_{2}$ and different sodium salts. However, it is only in the last decades especially since the 1990s that alkali activation research has grown significantly in the world due to the environmental issues related to the Portland cement. The advantage of these binders is that large variety of alumino-silicate material sources often industrial by-products such as fly ashes, slag with an amorphous phase can be activated. Several activators such as alkali sulfate, carbonate, hydroxide or silicate can be used. Alkali (especially $\mathrm{Na}$ or $\mathrm{K}$ ) silicates are by far the activators that lead to the formation of materials with higher performances $[9,10]$ and show the greatest industrial relevance in alkali activation [11].

Furthermore, non-recycled glass constitutes one of the most wastes produced in some countries and sets a major environmental issue. Unlike other forms of waste including paper or organic constituents, waste glass bottles will remain stable after their disposal in landfills. Although, this mineral material can be used several times without significant changes in its chemical and physical properties, the recycling of glass except for clear one, remains negligible. The use of GP in alkali activated system can be useful due to its alkali and silicate content. Actually the GP contains almost $13 \%$ of $\mathrm{Na}_{2} \mathrm{O}$. The high $\mathrm{Na}$ content of GP could allow to reduce the concentration of $\mathrm{NaOH}$ solution used as activator.

This paper deals with the development of waste glass powder based alkali-activated mortar. MK is used to replace a part of glass powder in order to introduce $\mathrm{Al}$ and thus form geopolymer gel. The microstructural and mechanical properties of mortars were investigated. 


\section{EXPERIMENTAL PART}

\subsection{Materials}

Table 1: Chemical composition of GP and MK

\begin{tabular}{|c|c|c|c|c|c|c|c|c|c|c|}
\hline \multirow[t]{2}{*}{ Materials } & \multicolumn{10}{|c|}{ Chemical composition } \\
\hline & $\mathrm{SiO}_{2}$ & $\mathrm{Al}_{2} \mathrm{O}_{3}$ & $\mathrm{Fe}_{2} \mathrm{O}_{3}$ & $\mathrm{CaO}$ & $\mathrm{MgO}$ & $\mathrm{SO}_{3}$ & $\mathrm{~K}_{2} \mathrm{O}$ & $\mathrm{Na}_{2} \mathrm{O}$ & LOI & $\mathrm{Na}_{2} \mathrm{O}_{\mathrm{eq}}$ \\
\hline Glass Powder & 72.66 & 1.57 & 0.39 & 11.41 & 1.24 & 0.07 & 0.54 & 12.89 & 0.38 & 13.24 \\
\hline Metakaolin & 49.92 & 27.61 & 12.28 & 3.71 & 0.93 & 0.30 & 1.82 & 0.35 & 1.90 & 1.54 \\
\hline
\end{tabular}

Table 2:Mix designs of geopolymer mortars.

\begin{tabular}{|c|c|c|c|c|c|c|c|c|}
\hline No & $\begin{array}{l}\text { Sol.NaOH/ } \\
\text { PV+MK }\end{array}$ & $\mathrm{E} / \mathrm{L} *$ & $\begin{array}{l}\text { Slump } \\
(\mathrm{mm})\end{array}$ & $\begin{array}{l}\text { PV } \\
(\%)\end{array}$ & $\begin{array}{l}\text { MK } \\
(\%)\end{array}$ & $\begin{array}{l}\mathrm{NaOH} \\
(\mathrm{M})\end{array}$ & $\mathrm{Si} / \mathrm{Al}$ & $\mathrm{Al} / \mathrm{Na}$ \\
\hline 1 & 0.60 & \multirow{6}{*}{0.45} & 210 & 100 & 0 & 5 & 39.29 & 0.05 \\
\hline 2 & 0.60 & & 210 & 97 & 3 & 5 & 21.33 & 0.09 \\
\hline 3 & 0.60 & & 210 & 95 & 5 & 5 & 16.29 & 0.12 \\
\hline 4 & 0.60 & & 210 & 92 & 8 & 5 & 11.98 & 0.16 \\
\hline 5 & 0.70 & & 230 & 95 & 5 & 8 & 16.29 & 0.09 \\
\hline 6 & 0.76 & & 230 & 95 & 5 & 10 & 16.29 & 0.08 \\
\hline
\end{tabular}

* Calculated considering the total water and the total solids (glass podwer+metakaolin+NaOH)

The glass powder obtained by milling mixed recycled bottle glass is provided by a sorting center. The mean diameter of particle size is about $13 \mu \mathrm{m}$ with a density of $2.56 \mathrm{~g} / \mathrm{cm}^{3}$ and a fineness of $4400 \mathrm{~cm}^{2} / \mathrm{g}$. Its chemical composition shown in Table 1 is determined by X-ray fluorescence by means of Axios-Advenced apparatus. The so-called soda-lime silicate glass powder is mainly composed of $72 \% \mathrm{SiO}_{2}, 13 \% \mathrm{Na}_{2} \mathrm{O}$ and $11 \% \mathrm{CaO}$. The metakaolin provided by a local company is obtained by calcining kaolin at $700^{\circ} \mathrm{C}$ (Table 1). Its density and fineness are $2.67 \mathrm{~g} / \mathrm{cm}^{3}$ and $21400 \mathrm{~cm}^{2} / \mathrm{g}$ respectively. GP and MK are both amorphous. However, MK contains a crystalline phase such as quartz. $\mathrm{NaOH}$ solutions with concentrations of 5, 8 and $10 \mathrm{M}$ prepared by dissolving $\mathrm{NaOH}$ pellets $(99 \%)$ in distilled water were used to activate the glass powder containing 0,5 and $8 \%$ of $\mathrm{MK}$ as replacement.

\subsection{Mortars Mixed and Methods}

Mortars composed of 1 part binder and 2.75 parts of sand were made in accordance with the ASTM C 109 standard using Ottawa normalized sand. The water to binder ratio was 0.45 for all samples. In order to dissolve a part of amorphous silica, the glass powder was mixed with $\mathrm{NaOH}$ solution during 2 minutes. MK was immediately added and the procedure for mixing mortar recommended by the ASTM C305 standard was followed. Flow of geopolymer mortars was measured under the fixed designation according to the ASTM C 1437 standard and the results are showed in Table 2 along with the mix designs. Mortars samples were thermally activated at $60^{\circ} \mathrm{C}$ during 2 days and cured at $20{ }^{\circ} \mathrm{C}$ and $50 \%$ humidity until the compressive strength tests at 7 , 28 and 91 days. Compressive strength were conducted on the $50 \times 50 \times 50 \mathrm{~mm}$ cubes in accordance with the ASTM C109 standard. Microstructural changes were also studied according to the $\mathrm{MK}$ content and $\mathrm{NaOH}$ concentration at 28 days using a scanning electron microscopy coupled with energy dispersive X-ray microanalysis (SEM/EDS).

\section{RESULTS AND DISCUSSION}

\subsection{Compressive Strength}

\subsubsection{Effect of Metakaolin Content}

Fig. 1 shows the effect of the MK content on the compressive strength of mortar. The incorporation of MK in the glass powder leads to a decrease in the compressive strength at 7 days. This can be explained by the formation of $\mathrm{Si}-\mathrm{O}-\mathrm{Al}$ bonds which are less strong than $\mathrm{Si}-\mathrm{O}-\mathrm{Si}$ present in the activated GP without MK. The compressive strength decreases with time for mortars that contain up to $3 \%$ (samples 1,2) of MK. However, when the MK content is superior or equal to $5 \%$ (samples 3,4 ), the compressive strength which was initially low increases with the time. The decrease in the compressive strength of mortars that contain low MK could be due to the high free alkali content. As MK is well known to possess good capability to fix alkali ions [12]. The fixation of alkali ion within the geopolymer matrix make denser and compacter the gel leading to a progressive increase in the resistance. Therefore, a decrease in the silica 
content, i.e. from $\mathrm{Si} / \mathrm{Al}$ ratio of 39.29 (sample $1,0 \% \mathrm{MK}$ ) to 11.98 (sample 4, 8\% MK) leads to an improvement of the compressive strength that increases gradually. These results are in accordance with those observed by Lee et al [13].According to these authors, an increase in the silica content or the rise in Si/Al modulus makes difficult the formation of the gel by reducing the bonds between particles inducing a decrease in the resistance with the time.

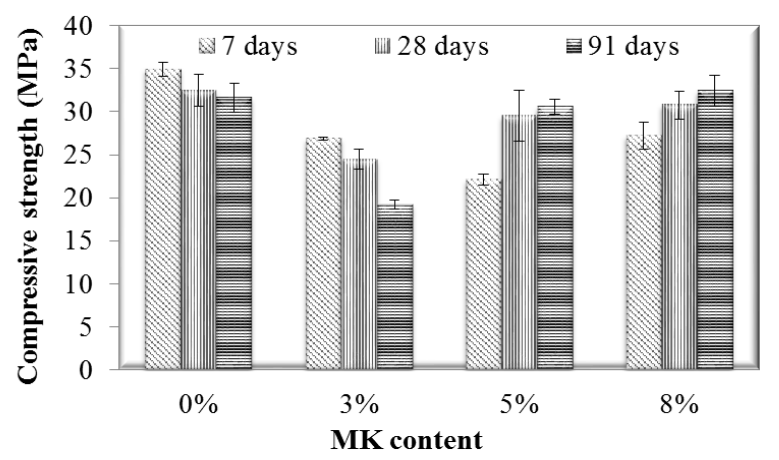

Fig. 1: Effect of the MK content (samples 1-4) on the compressive strength of mortars activated with $\mathrm{NaOH} 5 \mathrm{M}$.

\subsubsection{Effect of $\mathrm{NaOH}$ Concentration}

The effect of $\mathrm{NaOH}$ concentration was also studied and the results are presented in the Fig. 2 for samples containing $5 \%$ of MK (samples 3, 5 and 6). The compressive strength decreases with increasing $\mathrm{NaOH}$ concentration. This result suggests a delay in the geopolymerization process when the concentration is too high due to the limitation of the ion mobility and the stability of ions species [12]. In fact, the rate of dissolution of aluminosilicates in alkaline solutions increases with the hydroxide ion concentration. Alonso and Palomo [12]pointed out that a high concentration of the activator fosters the dissolution process of the solid network but delays the geopolymerization due to the low mobility of alkali ions and thus limiting their diffusion through the solution. The excess of $\mathrm{NaOH}$ could induce the formation of a non-uniform reaction product resulting in a reduction of the gel resistance. These results suggest the existence of a threshold concentration beyond which a higher concentration of sodium hydroxide may cause an increase in the amount of dissolved species, and their great difficulty to diffuse into the aqueous phase. In addition, the Na content of the glass powder induces an increase in such an ion in the system. Therefore, for glass powder-based geopolymer, low concentrations of activator will be sufficient to obtain good mechanical properties especially in the conditions of our study.

\subsection{Microstructural Study}

\subsubsection{Effect of Metakaolin Content}

Fig. 3 gathers the microstructures of GP mortar activated with and without MK after 28 days of reaction. The activator used is a $\mathrm{NaOH}$ solution of $5 \mathrm{M}$. A denser matrix can be observed in the presence of metakaolin with more cohesion between the sand grains and the paste.

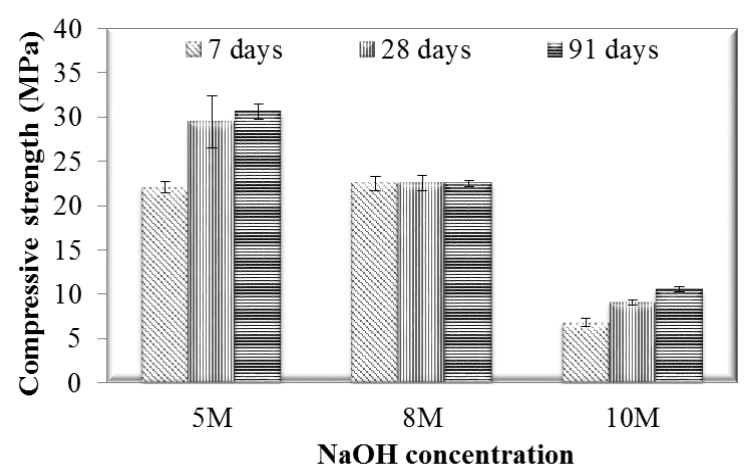

Fig. 2: Effect of $\mathrm{NaOH}$ concentration (samples 3, 5, 6) on the compressive strength of GP mortars containing 5\% MK.

In contrast the GP mortar activated without metakaolin shows low cohesion between the paste and aggregates. These results are in accordance with the gradual enhancement of the compressive strength when MK was added unlike its decrease without or with low $(\leq 3 \%)$ MK content. The improvement of the microstructure features of mortars containing $8 \%$ MK can be attributed to the stabilization of some alkali ions in the NASH gel formed due to the introduction of aluminum from MK. Since it is well known that in the framework of geopolymer gels, the $\mathrm{Si}^{4+}$ and $\mathrm{Al}^{3+}$ cationsare tetrahedrally coordinated and linkedby oxygen bridges and the negative charge on the $\mathrm{AlO}_{4}^{-}$is chargebalanced with alkali cations $\left(\mathrm{Na}^{+}\right.$or $\left.\mathrm{K}^{+}\right)[14]$.Thus, in such a system, alkalis are fixed and constitute part of the gel network unlike in the mortar without metakaolin where unbound alkali can weaken the gel network resulting in low cohesion and the decrease in the compressive strength.
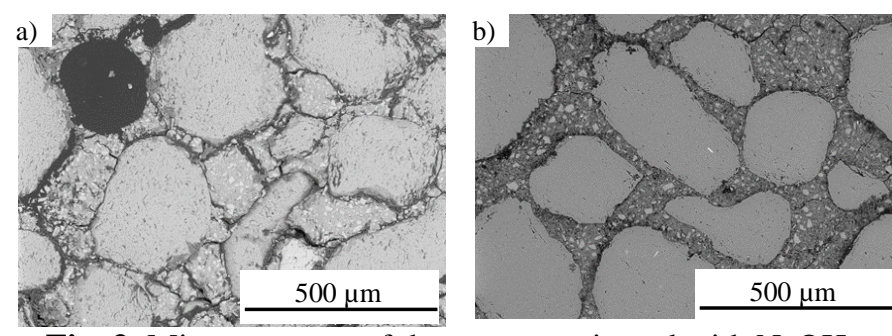

Fig. 3: Microstructure of the mortar activated with $\mathrm{NaOH}$ $5 \mathrm{M}$ after 28 days: a) $0 \%$ of MK (sample 1) and b) $8 \%$ of MK (sample 4).

The energy dispersive spectroscopy (EDS) microanalysis of the gel reveals the presence of calcium silicate hydrate $(\mathrm{C}(\mathrm{N})-\mathrm{S}-\mathrm{H})$ type gel in the GP mortar activated without MK (Fig 4, a (A)). This gel has almost the same composition asthe glass powder(Table 1) with similar $\mathrm{Na}_{2} \mathrm{O} / \mathrm{SiO}_{2}$ molar ratio $(\sim 0.18)$. However, the calcium content in the gel seems to be high, as $\mathrm{Na}_{2} \mathrm{O} / \mathrm{CaO}$ decreases from 1.2 in the glass particle to 0.79 in the gel confirming the formation of $\mathrm{C}-\mathrm{S}-\mathrm{H}$ type gelwith very low $\mathrm{C} / \mathrm{S}(0.23)$ ratio allowing the incorporation of a high amount of sodium cations. Furthermore, in the presence of MK, both C-S-H and N-A$\mathrm{S}-\mathrm{H}$ are present (Fig 4, b). The formation of both gels indicates the glass powder dissolution and also the participation of metakaolin in the gel formation resulting in the reductionof $\mathrm{SiO}_{2} / \mathrm{Al}_{2} \mathrm{O}_{3}$ ratio from almost infinity to 
approximately $8 \%$. In addition, the decrease in $\mathrm{Na}_{2} \mathrm{O} / \mathrm{Al}_{2} \mathrm{O}_{3}$ ratio to 1.90 confirms the fixation of a large amount of alkali ions by aluminum atom from the metakaolin and the stability of ions species through thecharged-balance with $\mathrm{Na}^{+}$cations inside the gel structure further to the substitution of $\mathrm{Si}^{4+}$ atoms by $\mathrm{Al}^{3+}$ atoms $[14,15]$.

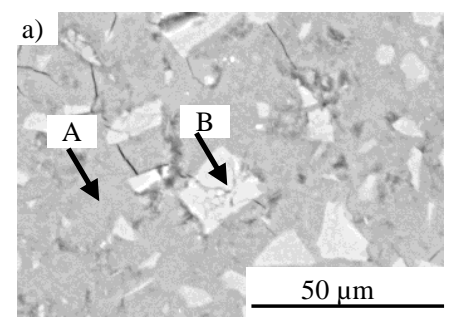

\begin{tabular}{|l|l|l|}
\hline Ratio & $\mathrm{A}$ & $\mathrm{B}$ \\
\hline $\mathrm{SiO}_{2} / \mathrm{Al}_{2} \mathbf{O}_{3}$ & - & - \\
\hline $\mathrm{Na}_{2} \mathrm{O} / \mathrm{SiO}_{2}$ & 0.18 & 0.18 \\
\hline $\mathrm{Na}_{\mathbf{2}} \mathrm{O} / \mathrm{Al}_{2} \mathbf{O}_{3}$ & - & - \\
\hline $\mathrm{CaO} / \mathrm{SiO}_{2}$ & 0.23 & 0.23 \\
\hline $\mathrm{Na}_{2} \mathrm{O} / \mathrm{CaO}$ & 0.79 & 0.90 \\
\hline
\end{tabular}

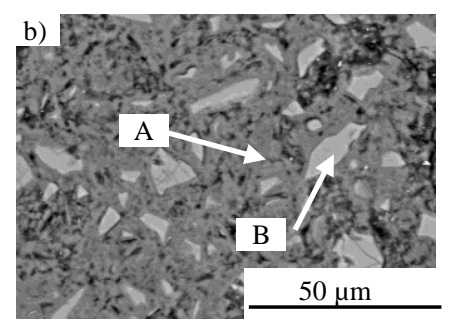

\begin{tabular}{|l|l|l|}
\hline Ratio & A & B \\
\hline $\mathrm{SiO}_{2} / \mathrm{Al}_{\mathbf{2}} \mathbf{O}_{3}$ & 8.10 & - \\
\hline $\mathrm{Na}_{2} \mathbf{O} / \mathrm{SiO}_{2}$ & 0.20 & 0.18 \\
\hline $\mathrm{Na}_{\mathbf{2}} \mathrm{O} / \mathrm{Al}_{\mathbf{2}} \mathbf{O}_{3}$ & 1.90 & - \\
\hline $\mathbf{C a O} / \mathrm{SiO}_{\mathbf{2}}$ & 0.20 & 0.23 \\
\hline $\mathrm{Na}_{\mathbf{2}} \mathbf{O} / \mathbf{C a O}$ & 1.23 & 0.90 \\
\hline
\end{tabular}

Fig. 4: EDS of the mortar activated with $\mathrm{NaOH} 5 \mathrm{M}$ after 28 days: a) $0 \%$ of MK (sample 1) and b) $8 \%$ of MK (sample 4), A: gel and B: unreacted glass particle.

\subsubsection{Effect of $\mathrm{NaOH}$ Concentration}

The changes in the microstructure of mortars according to the $\mathrm{NaOH}$ concentration is shown in Fig.5. The increase in the concentration of $\mathrm{NaOH}$ solution from $5 \mathrm{M}$ to $10 \mathrm{M}$ induces the formation of a heterogeneous gel resulting in a significant carbonation (dark part) due to the high amount of unbound alkali ions. This is in line with the decrease in the compressive strength when the $\mathrm{NaOH}$ concentration increases. Moreover, the cohesion between the paste and aggregates lowers with $\mathrm{NaOH}$ concentration.

In addition, for the $\mathrm{NaOH}$ concentration of $10 \mathrm{M}$ (Fig 5c), the gel seems to be absent confirming the delay in the geopolymerization process with high $\mathrm{NaOH}$ concentration. Therefore, the increase in the $\mathrm{NaOH}$ concentration promotes the dissolution process instead of geopolymerization [12]. As already observed with samples containing various amount of metakaolin, the EDS results corroborate the presence of both C-S-H and N-A-S-H gel for $\mathrm{NaOH}$ concentration of $5 \mathrm{M}$ and $8 \mathrm{M}$ (Fig $6 \mathrm{a} \& \mathrm{~b}$ ). However, no gel can be observed with $\mathrm{NaOH}$ concentration of 10M (Fig. 6c) Instead, the chemical analysis reveals high level of carbonation for the $10 \mathrm{MNaOH}$ samples resulting in a strong concentration of carbon $(70.7 \%)$. This result is in accordance with the prevalence of the dissolution over the geopolymerization.Thus, in such a system, low $\mathrm{NaOH}$ concentration $(\sim 5 \mathrm{M})$ is enough to form geopolymer gels with good performance.
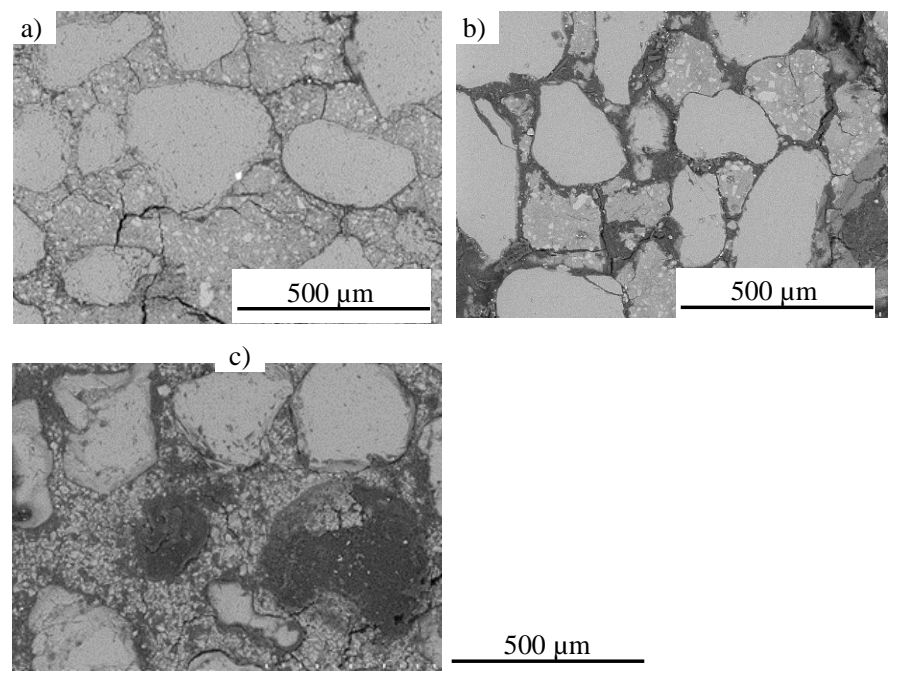

Fig. 5: Microstructure of the mortar containing 5\% MK activated with: a) $5 \mathrm{M}$ (sample 3), b) $8 \mathrm{M}$ (sample 5) and c) $10 \mathrm{M}$ (sample 6) of $\mathrm{NaOH}$ after 28 days of reaction.

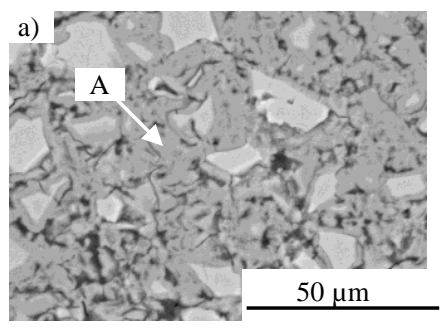

\begin{tabular}{|c|c|}
\hline Ratio & $\mathbf{A}$ \\
\hline $\mathrm{SiO}_{2} / \mathrm{Al}_{2} \mathrm{O}_{3}$ & 23.75 \\
\hline $\mathrm{Na}_{2} \mathrm{O} / \mathrm{SiO}_{2}$ & 0.19 \\
\hline $\mathrm{Na}_{2} \mathrm{O} / \mathrm{Al}_{2} \mathrm{O}_{3}$ & 4.47 \\
\hline $\mathrm{CaO} / \mathrm{SiO}_{2}$ & 0.20 \\
\hline $\mathrm{Na}_{2} \mathrm{O} / \mathrm{CaO}$ & 0.93 \\
\hline
\end{tabular}

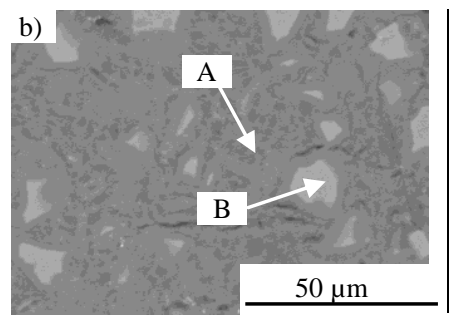

\begin{tabular}{|l|l|l|}
\hline Ratio & A & B \\
\hline $\mathrm{SiO}_{2} / \mathrm{Al}_{2} \mathbf{O}_{3}$ & 29.60 & - \\
\hline $\mathrm{Na}_{2} \mathrm{O} / \mathrm{SiO}_{2}$ & 0.19 & 0.18 \\
\hline $\mathrm{Na}_{\mathbf{2}} \mathrm{O} / \mathrm{Al}_{2} \mathbf{O}_{3}$ & 5.75 & - \\
\hline $\mathbf{C a O} / \mathrm{SiO}_{2}$ & 0.20 & 0.23 \\
\hline $\mathrm{Na}_{\mathbf{2}} \mathrm{O} / \mathrm{CaO}$ & 0.93 & 0.90 \\
\hline
\end{tabular}

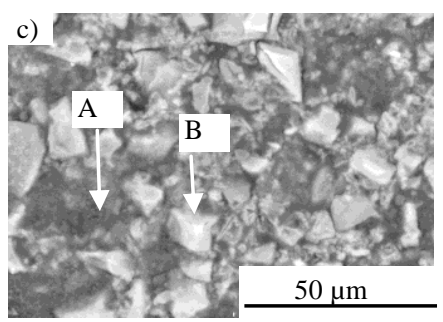

\begin{tabular}{|l|l|l|}
\hline & $\mathbf{A}^{*}$ & $\mathbf{B}^{*}$ \\
\hline $\mathbf{C}$ & 70,69 & 39.95 \\
\hline $\mathbf{O}$ & 17,09 & 34.38 \\
\hline $\mathbf{N a}$ & 1,63 & 4.07 \\
\hline $\mathbf{A l}$ & 0,38 & 1.56 \\
\hline $\mathbf{C a}$ & 1,66 & 2.86 \\
\hline $\mathbf{S i}$ & 8.54 & 17.19 \\
\hline
\end{tabular}

Fig. 6: EDS of the mortar containing 5\% MK activated with: a) $5 \mathrm{M}$ (sample 3), b) $8 \mathrm{M}$ (sample 5) and c) $10 \mathrm{M}$ (sample 6) of $\mathrm{NaOH}$ after 28 days of reaction. A: gel and $\mathrm{B}$ : unreacted glass particle

\section{CONCLUSIONS}

This study shows the possibility to use glass powder as material source and activator precursor. Indeed, the activation of glass powder allow the use of less concentrated sodium hydroxide $(5 \mathrm{M})$. The addition of aluminum source such as metakaolin is necessary to fix alkali ions in the matrix and thus form a denser gel. The activation of glass 
powder reveals the presence of calcium silicate and sodium silicate hydrate $(\mathrm{C}(\mathrm{N})-\mathrm{S}-\mathrm{H})$ type gel while in the presence of $\mathrm{MK}$, both C-S-H and N-A-S-H are present. The presence of $\mathrm{N}-\mathrm{A}-\mathrm{S}-\mathrm{H}$ type gel due to the addition of MK, allows the stabilization of alkali ions. In this work, only up to $8 \%$ of MK can be added, which is not enough to stabilize all alkali ions. But, above $8 \%$ of MK, the workability is worst due its high fineness.

Therefore, the next step of this work will be focused on the study of the effect of superplasticizer on the workability of GP mortar containing high amount of MK in order to find a suitable dispersant agent.

\section{ACKNOWLEDGEMENTS}

The authors gratefully acknowledge the financial support of the Industrial Chair on the Valorization of Glass in Materials provided by the Société des Alcools du Quebec (SAQ).

\section{REFERENCES}

[1]. Taylor, M., Tam, C. and Gielen, D., "Energy efficiency and $\mathrm{CO}_{2}$ emissions from the global cement industry". International Energy Agency, 2006.

[2]. CEMBUREAU, the European Cement Association (http://www.cembureau.eu/about-cement/key-facts-figures) accessed on 21022014.

[3]. Scrivener, K.L. and Kirkpatrick, R.J., "Innovation in use and research on cementitious material". Cem. Concr. Res. 38(2), 2008, pages: 128-136.

[4]. World Business Council for Sustainable Development, "L'initiative ciment pour le développement durable - Notre programme d'action". United Kingdom, ISBN 2-240940-41$8,2002$.

[5]. Committee on the science of climate change, National Research Council, 2001; CBS NEWS, 6/19/2003; Boston Globe, 6/20/2003.

[6]. Kühl, H., "Slag cement and process of making the same". U.S. Patent 900,939, USA, 1908.

[7]. Purdon, A.O., "The action of alkalis on blast-furnace slag”. J. Soc. Chem. Ind.- Trans. Commun. 59, 1940, pages: 191-202.

[8]. Purdon, A.O., "Improvements in processes of manufacturing cement, mortars and concretes". British Patent GB427,227, United Kingdom, 1935.

[9]. A. Fernandez-Jimenez, A. Palomo, "Composition and microstructure of alkali activated fly ash binder: Effect of the activator". Cement and Concrete Research 35, 2005, pages: $1984-1992$

[10]. A. Palomo, M.W. Grutzeck, M.T. Blanco, "Alkali activated fly ashes: a cement for the future". Cem. Concr. Res. 29 (8), 1999, pages: 323-1329.

[11]. Provis, J.L., "Activating solution chemistry for geopolymers In Provis, J.L. and van Deventer, J.S.J. (Editions) Geopolymers: Structure, Processing, Properties and Industrial Applications, Woodhead, Cambridge, UK, 2009, pages: 50-71.

[12]. Alonso, S., Palomo, A.,"Alkaline activation of metakaolin and calcium hydroxide mixtures: Influence of temperature, activator concentration and solids ratio". Materials Letters, 47(1-2), 2001a, pages: 55-62.

[13]. Lee, W.K.W., Van Deventer, J.S.J.,"Effects of anions on the formation of aluminosilicate gel in geopolymers". Industrial and Engineering Chemistry Research,volume 41(18), 2002, pages: 4550-4558.

[14]. Duxson, P., Fernandez-Jimenez, A., Provis, J.L., Lukey, G.C., Palomo, A., van Deventer, J.S.J., "Geopolymer technology: the current state of the art", J Mater Sci.,42, 2007, pages: 2917-2933.

[15]. Davidovits, J., "Chemistry of geopolymeric systems". In: Terminology. Proceedings of 99 geopolymer conference, volume 1St. Quentin (France), 1999,pages: 111-120.

\section{BIOGRAPHIES}

Balaguer Ana Pascual, received her first degree in Chemical Engineering in 2010 from the University of Valencia, Spain followed by a 6-month training in 20102011 at AIDICO in Valencia. She is currently a Master candidate in the Department of Civil Engineering at the University of Sherbrooke (UdeS), Quebec, Canada.

Tohoue Monique Tognonvi, obtained her $\mathrm{PhD}$ degree in chemistry of materials from the University of Limoges, France, in 2009 follow by two-year postdoctoral research in the laboratory of Heterogeneous Materials Group in Limoges. She is currently a postdoctoral fellow in the Department of Civil Engineering at UdeS. Her research interests include alternative cementitious materials.

Arezki Tagnit-Hamou is a full professor of civil Engineering at UdeS. He is a Fellow of the American Concrete Institute and the RILEM. He is holding the Industrial Chair for Research in the area of valorization of waste glass in materials and is the Director of the Research Laboratory on Alternative Cementitious Materials of UdeS. His research interests include the development of ecological concretes and the valorization of by-products. 